\title{
Materiale document: primii ani ai Facultății de Silvicultură din Suceava
}

\author{
Sergiu Andrei Horodnic \\ Universitatea „Ștefan cel Mare" din Suceava, Facultatea de Silvicultură
}

Rubrica „Restituiri” este dedicată aniversării celor 30 ani de învățământ silvic superior la Suceava și grupează trei dintre materialeledocument ce sunt readuse atenției cititorilor cu scopul vădit de a le primeni amintirile unora sau de a oferi altora câteva pagini din istoria acestei instituții ce ar fi putut rămâne ascunse în rafturile prăfuite ale arhivei.

Pentru a înțelege cum a luat ființă Facultatea de Silvicultură din Suceava este nevoie de un exercițiu de imaginație pentru cei care nu au fost direct implicați, care necesită totuși niște repere de prezentare a contextului general al stării Universității „Ștefan cel Mare” în 1990. Astfel se justifică includerea unui prim material ce oferă informații privind cadrul existent la acea vreme, cu câteva referiri la istoricul Institutului de Învățământ Superior din Suceava, la numărul de studenți pe profiluri și forme de învățământ la momentul transformării în Universitate, la spațiile de învățământ și

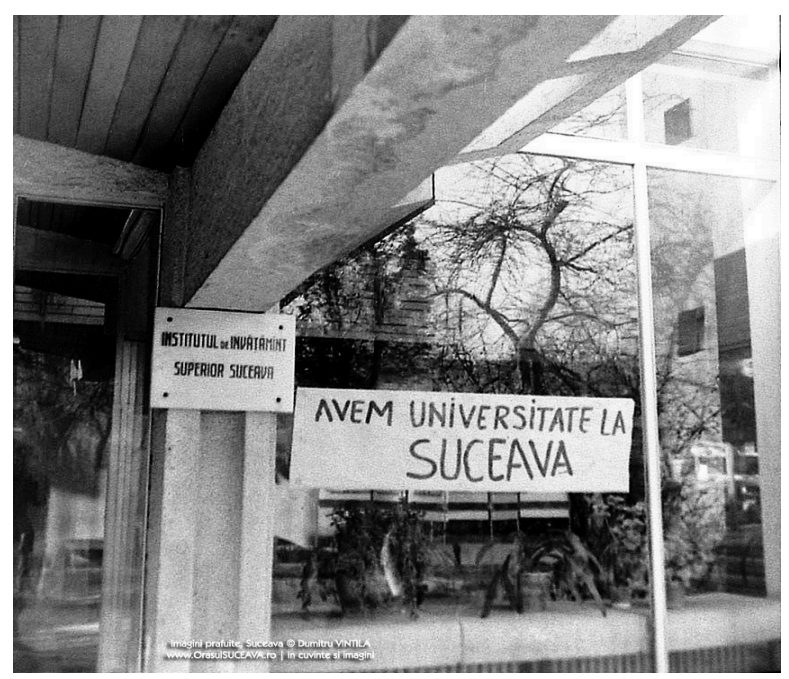
cadrele didactice existente, precum și, foarte interesant pentru facultatea noastră, o listă cu cadre didactice propuse a fi încadrate la specializarea „Silvicultură și Exploatare Forestieră”, cum s-a intenționat să se numească inițial.

Perioada de început, anevoioasă şi plină de provocări, a fost marcată de puternica personalitate a profesorului Ioan Milescu, cel care şi-a asumat responsabilitatea conducerii proaspăt înființatei facultăţi în calitate de decan. Următoarele două documente reprezintă dovezi ale profesionalismului, tactului şi spiritului progresist care 1-au caracterizat.

„Învăţământ silvic superior la Suceava” este, pe de o parte, o declaraţie de ataşament la valorile tradiţionale şi o expresie a misiunii asumate de promovare a unui învățământ modern, iar pe de altă parte un apel la dezvoltarea colaborării cu Facultatea de Silvicultură și Exploatări Forestiere din Brașov în ,,aceeași misiune nobilă, (...) susținânduse și completându-se în direcția aceluiași scop final”. „Am împărtășit și susținut opinia că existența mai multor școli de același profil și nivel între fruntariile țării are menirea de a stimula procesul de învățământ și de cercetare științifică”, spunea profesorul Ioan Milescu.

Profilul profesional al viitorului inginer forestier este tema lucrării „Formarea specialiștilor silvici pentru silvicultura secolului XXI" susţinută la Academia Română în martie 1992. Ideile expuse atunci sunt mai valabile ca oricând astăzi: formarea unor „,specialiști integri, cu o largă orientare spre viitor”, „flexibilitatea procesului de învățământ”, pregătirea absolvenţilor complex şi multidisciplinar astfel încât aceştia „,să gândească şi să acționeze în mod independent, eliberați de stresul obligativității de a se încadra strict în norme sau diferite alte proceduri cu pretenții de generalizare”. Profesorul Ioan Milescu atenţiona cu acea ocazie asupra unui mare pericol: ,aspectele unor atitudini sau politici conjuncturale, ca și tentativele de a considera pădurea capital electoral se dovedesc dezastruoase pentru viitorul silviculturii”. Vi se pare cunoscut? 


\title{
Notă privind cadrul necesar desfășurării specializării „Silvicultură și exploatare forestieră”
}

\author{
UNIVERSITATEA „ŞTEFAN CEL MARE” SUCEAVA
}

INFORMARE

(răspuns la nota telefonică din 12 aprilie 1990 privind cadrul necesar desfășurării specializării „Silvicultură și exploatare forestieră”)

1. Scurt istoric

a) Prin H.C.M. nr 680/1963, în Suceava a fost înființat Institutul Pedagogic de 3 ani cu următoarele facultăți:

- Facultatea de Matematică, învățământ de zi, cu durata de 3 ani;

- Facultatea de Filologie, învățământ de zi, cu durata de 3 ani;

Număr de studenţi în anul universitar 1963/1964:

- Facultatea de Matematică $=41$ studenți;

- Facultatea de Filologie $\quad=78$ studenti;

Personal didactic în anul universitar 1963/1964 = total 14 cadre didactice, din care: un profesor, 0 conferenţiari, 7 lectori, 6 asistenți.

Până în anul 1977 s-au adăugat următoarele facultăţi:

- 1964, Facultatea de Istorie - Geografie,

- 1971, Facultatea de Educaţie Fizică,

- 1976, prin Decretul Consiliului de Stat nr.228 s-a înființat o secție de subingineri cu profil mecanic, specializarea Tehnologia Construcțiilor de Mașini (T.C.M.), învăţământ de zi și seral,

- 1977, prin Decretul Consiliului de Stat nr.209, Institutul Pedagogic s-a transformat în Institutul de Învăţământ Superior cu profil mixt, universitar și tehnic; la profilul universitar dispare specializarea Matematică - Fizică, în timp ce la profilul tehnic se înființează specializările: T.C.M., ingineri zi, și Tehnologia Produselor Alimentare de Origine Animală, subingineri zi.

b) Momentul maxim al dezvoltării a fost atins în anul universitar 1981/1982, institutul funcționând cu următoarele secții și forme de învățământ:

\begin{tabular}{|c|c|c|c|}
\hline $\begin{array}{l}\text { Nr. } \\
\text { crt. }\end{array}$ & Specializarea & Forma de învățământ & $\begin{array}{c}\text { Număr de } \\
\text { studenți }\end{array}$ \\
\hline 1. & T.C.M., ingineri & $\mathrm{zi}$ & 387 \\
\hline 2. & T.C.M., ingineri & seral & 60 \\
\hline 3. & T.C.M., subingineri & $\mathrm{zi}$ & 150 \\
\hline 4. & T.C.M., subingineri & seral & 272 \\
\hline 5. & $\begin{array}{l}\text { Tehnologia Produselor Alimentare de Origine } \\
\text { Animală (T.P.A.O.A.), subingineri }\end{array}$ & $\mathrm{zi}$ & 79 \\
\hline 6. & $\begin{array}{l}\text { Filologie, cu secțiile: } \\
\text { Limba și literatura română - limba franceză } \\
\text { Limba și literatura română - limba germană }\end{array}$ & zi & 72 \\
\hline 7. & Istorie - geografie & $\mathrm{zi}$ & 59 \\
\hline 8. & Educație fizică & $\mathrm{zi}$ & 40 \\
\hline \multirow[t]{2}{*}{9.} & Studenți străini, an pregătitor & $\mathrm{zi}$ & 240 \\
\hline & & TOTAL STUDENȚI: & 1359 \\
\hline
\end{tabular}

Cadre didactice $=$ total 95 , din care: 2 profesori, 7 conferențiari, 40 șefi lucrări/lectori, 46 asistenți. 
c) Evoluția după momentul maxim

Începând cu anul 1983, au fost lichidate, rând pe rând, secțiile de la profilul umanistic și tehnic, învățământ de zi, după cum urmează:

1983 - Educație fizică și T.C.M., subingineri zi,

1984 - T.P.A.O.A., subingineri zi,

1986 - Istorie - geografie,

1987 - Filologie,

1988 - T.C.M. ingineri zi,

1989 - Mașini și Utilaje de construcții, subingineri seral.

Menționăm că, începând cu anul 1984, institutului i s-a schimbat titulatura în Institut de Subingineri, prin Decretul consiliului de Stat nr.213 și Ordinul M.E.I. nr.3043/7.09.1984, subordonat Institutului Politehnic Iași, având structură de facultate cu autonomie în ce privește coordonarea creditelor bugetare.

Din anul 1985, institutului i s-a repartizat un număr de studenți din cifra de școlarizare a Institutului Politehnic Iași, la următoarele specializări:

- Mașini unelte, ingineri seral,

- Utilaj tehnologic pentru industria textilă, ingineri seral,

- Energetică industrială, ingineri seral.

Din anul 1986 s-a adăugat, în aceleași condiții, secția de Automatizări și calculatoare, ingineri seral.

2. Cifra actuală (din 1990, n.n.) de școlarizare pe profiluri și forme de învățământ

\begin{tabular}{clcc}
\hline Nr. crt. & \multicolumn{1}{c}{ Specializarea } & Forma de învătăământ & Număr de studenți \\
\hline 1. & T.C.M., ingineri & seral & 504 \\
2. & T.C.M., subingineri & seral & 308 \\
3. & Mașini unelte, ingineri & seral & 118 \\
4. & Utilaj tehnologic, ingineri & seral & 129 \\
5. & Automatizări și calculatoare, ingineri & seral & 191 \\
6. & Energetică, ingineri & seral & 157 \\
7. & Studenți străini, an pregătitor & zi & 85 \\
\hline & & TOTAL STUDENȚI: & 1492 \\
\hline
\end{tabular}

Rețeaua universitară conform aprobării pentru anul universitar 1990/1991

\begin{tabular}{clll}
\hline Nr. crt. & \multicolumn{1}{c}{ Secția } & Număr de locuri & \multicolumn{1}{c}{ Specializare } \\
\hline \multicolumn{2}{c}{ Facultatea de invățământ tehnic } & & flexibil pentru industria lemnului, \\
1. & Utilaj tehnologic & 25 & minerit și industria textilă \\
2. & Tribologie & 20 & \\
3. & T.C.M. & 25 & \\
4. & Mecatronică & 25 & \\
5. & Automatizări și calculatoare & 50 & \\
6. & Electromecanică & 25 & \\
7. $\quad$ Silvicultură & 40 & \\
Facultatea de invățământ universitar & & \\
1. $\quad$ Limba română - limba engleză & 20 & \\
2. $\quad$ Limba română - limba franceză & 20 & învățământ, muzeologie, arhivistică, \\
3. $\quad$ Istorie - geografie & 45 & arheologie-reconstituire, ecologie \\
4. $\quad$ Organizarea și conducerea activităților & 25 & \\
\hline
\end{tabular}


3. Spații de învăţământ

Universitatea „Ștefan cel Mare” din Suceava dispune de șase corpuri de clădiri cu următoarea destinație: două cămine studențești cu un total de 612 locuri de cazare, două corpuri de învăţământ cu un total de $10540 \mathrm{~m}^{2}$ suprafaţă desfăşurată, o cantină cu 250 locuri și o sală de sport.

Universitatea a primit recent, de la Primăria orașului Suceava, un etaj în corpul clădirii primăriei cu o suprafață totală desfășurată de $1110 \mathrm{~m}^{2}$. De asemenea, a primit un cămin cu 252 locuri de cazare situat la circa 250 m față de spațiul de învăţământ acordat în cadrul primăriei.

4. Cadre didactice existente pe funcții şi categorii de vârstă

\begin{tabular}{lccccc}
\hline \multirow{2}{*}{ Funcția didactică } & \multirow{2}{*}{$\begin{array}{c}\text { Total, din } \\
\text { care }\end{array}$} & $\begin{array}{c}\text { Vârsta } \\
25-45\end{array}$ & $\begin{array}{c}\text { Vârsta } \\
46-65\end{array}$ & $\begin{array}{c}\text { Vârsta titlu științific } \\
25-45\end{array}$ & $\begin{array}{c}\text { Vârsta științific } \\
\text { Profesor }\end{array}$ \\
\cline { 3 - 6 } Conferențiar & 1 & - & 1 & - & - \\
\hline Șef lucrări (lector) & 4 & - & 4 & - & - \\
Asistent & 31 & 6 & 4 & 12 & 9 \\
\hline \multicolumn{1}{c}{ TOTAL GENERAL } & 29 & - & - & 29 & - \\
\hline
\end{tabular}

4.1. Cadre didactice care urmează a fi încadrate la Universitatea din Suceava, specialitatea Silvicultură și Exploatare Forestieră

\begin{tabular}{|c|c|c|c|}
\hline Nr.crt. & Numele şi prenumele & Funcția & Specialitatea la care activează (disciplina) \\
\hline 1. & Giurgiu Victor & Prof.dr.doc. & $\begin{array}{l}\text { Biometrie, Amenajament, Ecologie şi } \\
\text { politică forestieră }\end{array}$ \\
\hline 2. & Geambaşu Nicolae & Dr.ing. & Pedologie, Soluri forestiere \\
\hline 3. & Barbu Ion & Dr.ing. & Meteorologie, Climatologie, pedologie \\
\hline 4. & Taras Seghedin & Dr.ing. & Botanică, Ecologie \\
\hline 5. & Cenușă Radu & Ing. doctorand & Fiziologie, Ecologie \\
\hline 6. & Grudnicki Margareta & Biolog & Botanică, Fiziologie, Fitopatologie \\
\hline 7. & Buzdugan Ioan & Dr.ing. & Soluri forestiere, Pedologie \\
\hline 8. & Olenici Nicolae & Ing. doctorand & Entomologie \\
\hline 9. & Ichim Radu & Dr.ing. & Ecologie forestieră \\
\hline 10. & Bîndiu Constantin & Dr.ing. & Ecologie forestieră \\
\hline 11. & Barbu Nicolae & Ing. & Topografie \\
\hline 12. & Bereziuc Rostislav & $\begin{array}{l}\text { Prof.dr.ing. } \\
\text { (pensionat) }\end{array}$ & Topografie, Drumuri forestiere \\
\hline 13. & Ceianu Igor & Dr.ing. & Protecția pădurilor \\
\hline 14. & Ciubotaru Costache & Dr.ing. & \\
\hline 15. & Isac Rodica & Cercetător dr. & \\
\hline $\begin{array}{l}16 . \\
17 .\end{array}$ & Toma I. & Dr.ing. & \\
\hline
\end{tabular}




\section{Învătământ silvic superior la Suceava'}

Începând cu anul universitar 1989/1990 funcționează la Suceava o nouă facultate de silvicultură. Înființată la propunerea autorităților locale și a fostului minister al apelor, pădurilor şi mediului înconjurător, Facultatea de Silvicultură întregește profilul Universității „STTEFAN CEL MARE” din Suceava, în cadrul căreia funcționează de mai mulți ani facultăţi de: litere și științe (specializări - limba și literatura română, limbi străine, istorie și geografie, organizarea și conducerea activităților din turism) și inginerie cu profil mecanic (specializări - mecatronică, tribologie, tehnologia construcțiilor de mașini, automatizări, electronică și electrotehnică).

Oportunitatea înființării unei asemenea facultăţi, menită să pregătească specialiști cu profil complex de cultură și exploatare ecologică a pădurilor, în condiții moderne, proprii gândirii tehnice a mileniului ce urmează, a izvorât din rațiuni sociale, ecologice, economice și naționale. A existat în această zonă a țării o administrație forestieră de rang superior, exercitată de către Fondul religionar greco-ortodox din Bucovina, cu sediul la Cernăuți, care decenii de-a rândul a practicat un sistem de gospodărire silvică intensivă. S-au acumulat, timp de aproape două secole, tradiții și experiențe silvice, cu largi ecouri în propășirea silviculturii românești și făurirea unei conștiințe forestiere la români, ce se justifică a fi pe deplin puse în valoare în anii care vin.

Concomitent, au funcționat instituții de învățământ silvic care au pregătit un număr impresionant de silvicultori de diferite nivele - de la pădurar la inginer - ce s-au impus prin probitate profesională și morală, gândire și fapte în tot ceea ce a realizat durabil silvicultura din România. Amintim doar că școala silvică de la Frătăuții Noi, de lângă orașul Rădăuți, funcționa în anul 1887, în paralel cu cea de la Brănești - Ilfov. Absolvenți ai Institutului

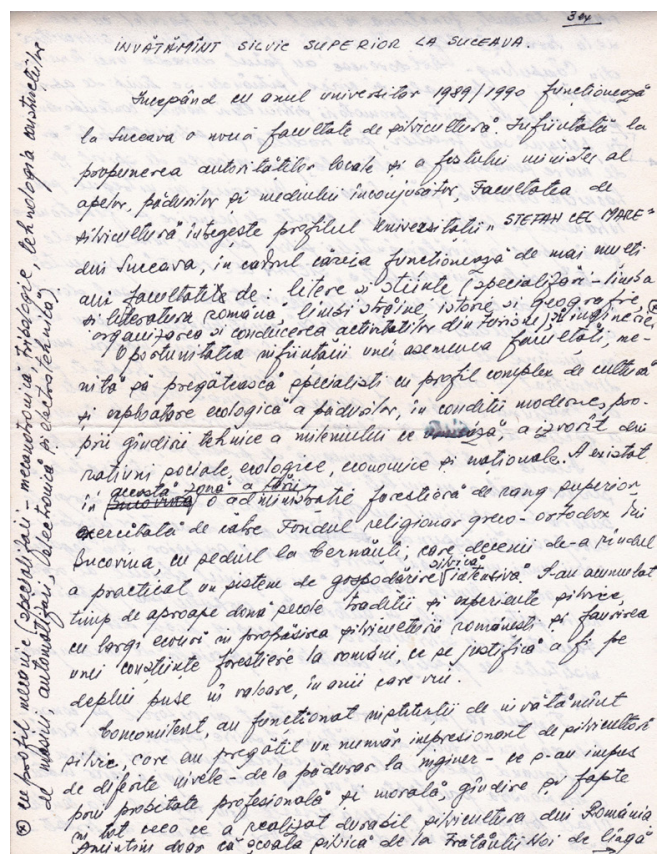

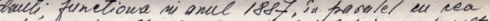

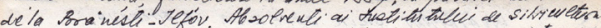

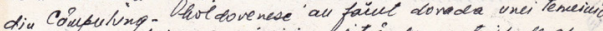

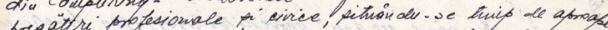

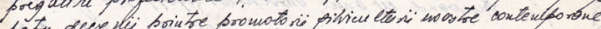

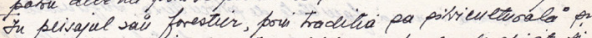
de nove pensibilitele notioxalo; pri enloores de obine to

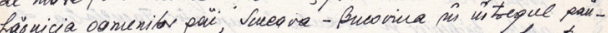

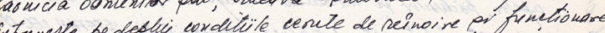

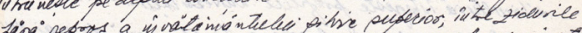

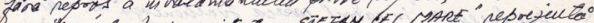

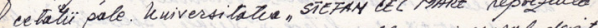
un blies de vertitidine fut tu desvoltarea mi seusal dine

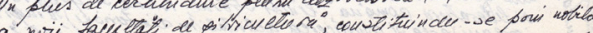

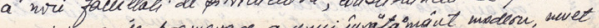

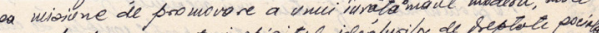

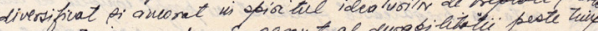

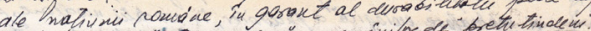

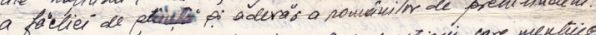

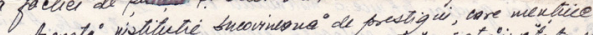

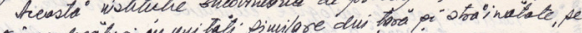

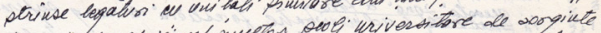

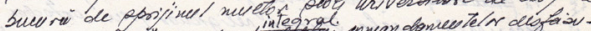

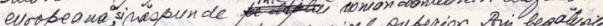

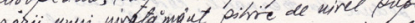

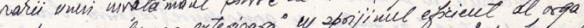

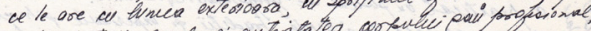

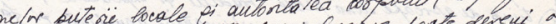

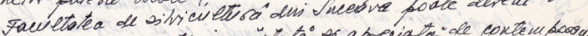

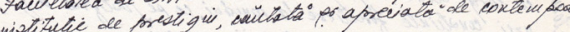
mostio

Timpule ro juea on ol inqbortant ni vitarul ps conso-

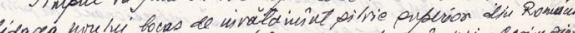

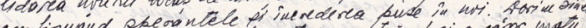

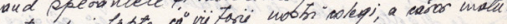

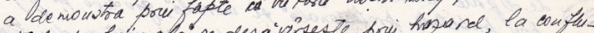

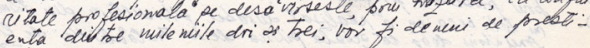

1) Milescu, I., 1990. Învățământ silvic superior la Suceava. Pădurea Noastră, 12 (revistă editată de Regia Autonomă a Pădurilor) 


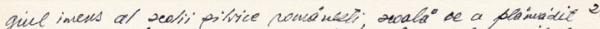

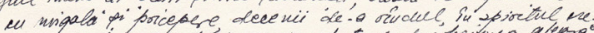

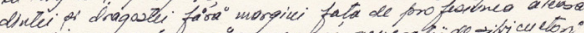

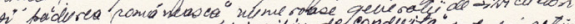

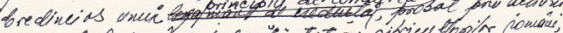

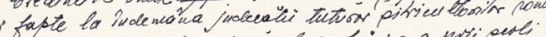

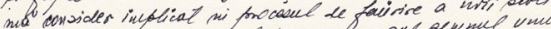
sitrice. Sornese te acest drem, corclom pat pew.

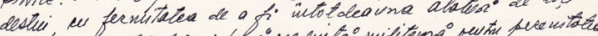

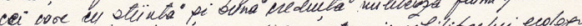

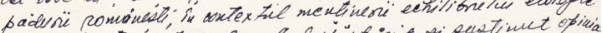

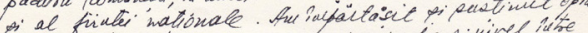

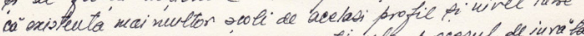

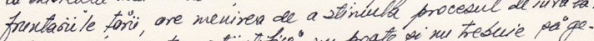

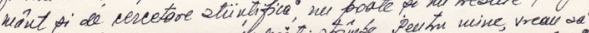

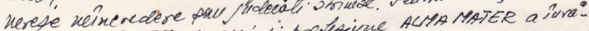

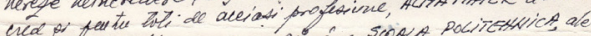

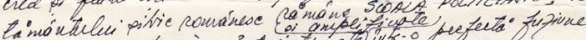

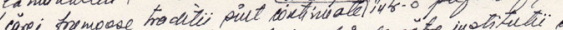

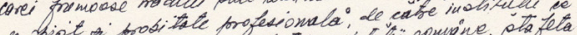

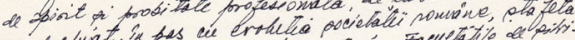

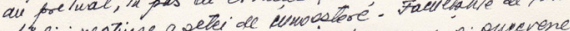

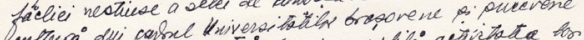

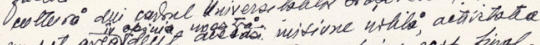

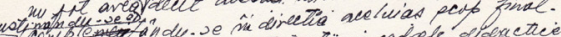

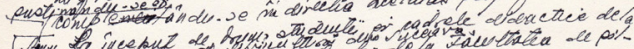

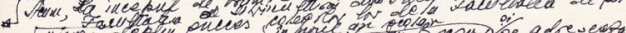

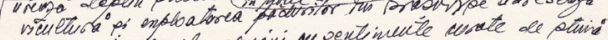

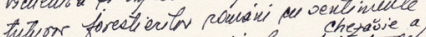

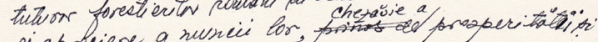

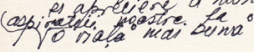

$$
\text { Prof. dr. ing. Loou Riseden. }
$$

de Silvicultură din Câmpulung Moldovenesc au făcut dovada unei temeinice pregătiri profesionale și civice, situându-se timp de aproape patru decenii printre promotorii silviculturii noastre contemporane.

În peisajul său forestier, prin tradiția sa silviculturală și de mare sensibilitate naţională, prin valoarea de spirit și hărnicia oamenilor săi, Suceava - Bucovina în întregul său - întrunește pe deplin condițiile cerute de reînnoire și funcționare fără reproș a învățământului silvic superior între zidurile cetății sale. Universitatea „ŞTEFAN CEL MARE” reprezintă un plus de certitudine pentru dezvoltarea în sensul dorit a noii facultăți de silvicultură, constituindu-se prin nobila sa misiune de promovare a unui învățământ modern, mult diversificat și ancorat în spiritul idealurilor de dreptate socială ale națiunii române, în garant al durabilității peste timp a făcliei de știință și adevăr a românilor de pretutindeni.

Această instituție bucovineană de prestigiu, care menține strânse legături cu unităţi similare din țară și străinătate, se bucură de sprijinul multor școli universitare de sorginte europeană și răspunde integral comandamentelor desfășurării unui învățământ silvic de nivel superior. Prin legăturile ce le are cu lumea exterioară, cu sprijinul eficient al organelor puterii locale și autoritatea corpului său profesional, facultatea de Silvicultură din Suceava poate deveni o instituție de prestigiu, căutată şi apreciată de contemporanii noștri.

Timpul va juca un rol important în viitorul și consolidarea noului locaş de învățământ silvic superior din România, confirmând speranțele și încrederea puse în noi. Dorim sincer a demonstra prin fapte că viitorii noștri colegi, a căror maturitate profesională se desăvârșește, prin hazard, la confluența dintre mileniile doi și trei, vor fi demni de prestigiul imens al școlii silvice românești, școală ce a plămădit cu migală şi pricepere, decenii de-a rândul, în spiritul credinței și dragostei fără margini față de profesiunea aleasă și pădurea românească, generații de silvicultori.

Credincios unui principiu de conduită, probat prin acțiuni și fapte la îndemâna judecății tuturor silvicultorilor români, mă consider implicat în procesul de făurire a noii școli silvice. Pornesc pe acest drum, oarecum sub semnul unui destin, cu fermitatea de a fi întotdeauna alături de toți cei care, cu știință și bună credință, militează pentru perenitatea pădurii românești, în contextul menținerii echilibrului ecologic și al ființei naționale. Am împărtășit și susținut opinia că existența mai multor școli de același profil și nivel între fruntariile țării are menirea de a stimula procesul de învățământ și de cercetare științifică; nu poate și nu trebuie să genereze neîncredere sau judecăți strâmbe. Pentru mine, vreau să cred că și pentru toți de aceeași profesiune, ALMA MATER a învățământului silvic românesc rămâne ȘCOALA POLITEHNICĂ, ale cărei frumoase tradiții sunt continuate și amplificate într-o perfectă fuziune de spirit și de probitate profesională, de către instituții ce au preluat, în pas cu evoluția societății române, ștafeta făcliei nestinse a setei de cunoaştere. Facultățile de silvicultură din cadrul Universităților braşovene şi sucevene nu pot avea, în opinia noastră, decât aceeași misiune nobilă, activitatea lor susținându-se și completânduse în direcția aceluiași scop final. 
Acum, la început de drum, studenții și cadrele didactice de la Facultatea de Silvicultură din Suceava urează deplin succes colegilor lor de la Facultatea de Silvicultură și Exploatări Forestiere din Brașov în noul an școlar și se adresează tuturor forestierilor români cu sentimente curate de stimă şi apreciere a muncii lor, chezăşie a prosperității și aspirației noastre la o viață mai bună.

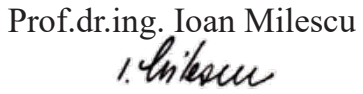

\section{Formarea specialiștilor silvici pentru silvicultura secolului XXI²}

Pădurile au impresionat întotdeauna prin masivitatea lor, prin dimensiunile remarcabile ale arborilor, prin bogăţia faunei și florei ce-și găsesc adăpost sub cupola ecosistemelor forestiere. Se recunoaște unanim că pădurile reprezintă cea mai cuprinzătoare comunitate de viață pe care o cunoaște planeta Pământ. Oriunde și oricând, ele se supun acelorași legi generale de organizare și funcționare, rămânând peste tot unitare în ceea ce privește natura lor intimă.

Dintotdeauna, omul a avut nevoie de adăpostul pădurii, încă din faza copilăriei sale, și oricât de avansată va fi tehnica pe care o va dezvolta în secolele următoare, va mai avea nevoie de produsele pădurii. Ne place să credem că omul mileniului trei, care va fi urmașul celui de astăzi, va căuta cu același viu interes frumusețea și utilitatea de neînlocuit ale pădurilor de mâine. Astfel înțeleg continuarea relațiilor existente dintre om și pădure, surprinse de altfel secole de-a rândul între confruntare și armonizare de interese, ce capătă în timp semnificații noi, complexe și de durată.

Un comportament civilizat, urmare a reflectării directe în rândul comunităților umane a conținutului învăţământului silvic, prin protejare întru perenitate a tot ceea ce este parte componentă a acestui patrimoniu al umanității - arbori, soluri, ape, arbuști, animale, flori - ne apropie de înțelegerea raporturilor pe care le au pădurile acum, la cumpăna dintre două milenii ale omenirii.

Definim programele cadru și profilul profesional al viitorului inginer forestier, acţionând în ideea că nu ne este îngăduit să uităm că am ieșit în luminișurile civilizației umane cu cutezanța și înțelepciunea de a ne desăvârși întru ființă și prin respectul față de pădure. Evaluând corect ceea ce s-a acumulat durabil, timp de peste un secol de funcționare a învățământului silvic superior în România, concepem formarea de noi specialiști în lumina adevărului netăgăduit că, de-a lungul devenirii neîntrerupte în spațiul locuit de români, nu ne-am trădat niciodată pădurea. Dimpotrivă, în casele noastre de lemn încercăm a ne prelungi visele de preamărire a împlinirilor la care ne dă dreptul efortul muncii de peste zi.

Am recurs în mod voit, la această mantie sentimental-educațională pentru a întări conținutul motivațiilor ce urmează cu privire la profilul profesional de mâine al inginerului forestier. $A c$ tivitatea acestuia se va înscrie inevitabil în convulsiile epocii pe care o traversăm - complexă, diversificată şi unică în felul său - supusă perpetuu unor transformări sociale, între care perioada de tranziție la acest final de secol reprezintă, pentru pădurea românească, drumul pe Golgota. Indiferent de locul unde își va desfășura activitatea, viitorul silvicultor se va confrunta cu noi obiective, cu tendințe imprevizibile pe care procesul de învățământ este, într-o manieră, obligat să i le previzioneze și explice pe băncile facultății.

Ne-ar fi greu și poate nici nu-i necesar să concepem un proces de învățământ forestier cu pretenții de valabilitate peste veac. Natura complexă a profesiunii ne obligă a forma specialiști integri, cu o largă orientare spre viitor, ceea ce impune procesului de învățământ un caracter interdisciplinar. Educaţia profesională a inginerului forestier trebuie să-i confere aptitudini de receptivitate pentru

2) comunicare la simpozionul „Pădurile secolului XXI în Romania” organizat de Academia Română, Secția de științe agricole și silvice, 17 martie 1992 
tot ceea ce reprezintă noutate în biologie și tehnică. Cunoștințele dobândite în diferite domenii ale ştiinței și tehnologiile de aplicat ce se recomandă pentru unele activităţi, indisolubil legate de regenerarea pădurii și utilizarea lemnului, pot deveni, prin forța lucrurilor, perimate.

Flexibilitatea procesului de învățământ, în profesiunea noastră adăugând și complexitatea acestuia, alimentate în mod permanent cu o documentare ce trebuie să devină realmente parte componentă a fluxului informațional din școli și universități, se consideră repere ale înțelegerii rostului de modernizare a învățământului silvic superior. Oportunitatea cunoașterii cadrului istoric și social, a impactului cerințelor ecologice și economice asupra naturii proprietății pădurilor și modului de folosinţă a produselor acestora, asupra amplificării gamei de servicii oferite societății de către vegetaţia forestieră, impun o reconsiderare a disciplinelor de studiu și a programelor analitice ale acestora. Este justificată o asemenea reconsiderare din acest moment pentru a pregăti viitorul specialist în raport cu mutațiile posibile în diferite domenii ale vieții economice și sociale.

Nu înțelegem printr-o asemenea reconsiderare modificări cu caracter conjunctural sau de conveniență. Existența și funcționarea învățământului silvic superior timp îndelungat în cadrul Școlii Politehnice din București reprezintă trepte câștigate în direcția făuririi unui concept național de școală silvică, o tradiție zămislită timp de decenii și grație activității notabile a absolvenților români ai școlilor forestiere de la Nancy, Viena sau Sankt Petersburg care, finalmente spre lauda lor, au respins aplicarea de jaloane și precepte de împrumut în silvicultura românească.

Din aceste considerente milităm pentru introducerea în planul de învăţământ al facultății de silvicultură, alături de elemente de informatică, automatizări, cultură și civilizație - deja cuprinse în procesul de studiu al studenților actuali - și discipline noi ca: industrializarea primară a lemnului, finanțe-credit, contabilitate, drept și legislație.

Avem îndatorirea ca la formarea de specialiști silvici, care să gestioneze pădurile secolului XXI, să punem în valoare suma cunoștințelor acumulate prin cercetări valoroase în pădurile din spațiul carpato-dunărean, precum și bogata experiență practică a multor generații de silvicultori. Din acest unghi, raporturile de dorit între profilul complex, multidisciplinar, al viitorului inginer silvic și specializarea în diferite domenii, pot constitui un subiect de discuție. Nu excludem ca în această profesiune atât de complexă, în care toate tehnologiile ce se aplică sunt subordonate conceptual și economic cerințelor ecologiei moderne, să coexiste astfel de raporturi pe baze opționale ale studenților după parcurgerea primilor trei ani din durata procesului de învățământ pentru ingineri, cursuri de zi.

Oricare ar fi condițiile fizico-geografice și sociale ale zonelor în care urmează să-şi desfăşoare activitatea viitorii ingineri silvici, aceștia trebuie să gândească şi să acționeze în mod independent, eliberați de stresul obligativității de a se încadra strict în norme sau diferite alte ,proceduri” cu pretenții de generalizare a soluțiilor tehnice pe întreg teritoriul național. Participarea fiecăruia la definirea programelor de lucru vizând mai corecta amenajare și gestiune a pădurilor presupune modelarea, din stadiul de formare, a capacității sale de ințelegere și finalizare a strategiei dezvoltării comunităților umane, cu deosebire a celor rurale.

Aria de cuprindere a unui inginer silvic se înscrie într-un cadru natural, în interiorul căruia interferarea de interese ca și jocul necunoscutelor generatoare de conflicte îi pot capta atenția, influențându-i chiar verticalitatea. Tăria de caracter, demnitatea profesiunii alese, integritatea sa prin diversitatea situațiilor posibile de lucru și contacte sociale, reprezintă atribute pe care școala le modelează, formând de acum, desigur pe fondul aptitudinilor native, personalitatea specialiștilor care vor depăși durata minimă a stagiului în producție odată cu zorii secolului XXI.

Capacitatea de a înțelege rolul economic ce revine sectorului forestier într-o țară cu resurse limitate cum este România, modul de integrare a pădurilor și industriilor de exploatare și prelucrare a lemnului într-o economie liberă, modernă, reprezintă imperative pentru cei ce pretind a concepe o politică forestieră coerentă. În accepțiunea de economie liberă, când este vorba de păduri, cu 76 
prisosinţă se impune o anumită particularizare. Exemplul pornirilor atavice ale multora, manifestate în prezent prin comportamente primare, dureroase atât pentru societate, cât și pentru integritatea fondului forestier naţional, reprezintă o realitate crudă a tăierilor ilegale fără precedent.

Slujitorii pădurilor sunt primii implicați, chiar cu mari riscuri, în educaţia civică a respectului față de păduri, în apărarea integrității acestora. Noțiunile obținute în școală țintesc formarea de oameni fermi, curajoși, capabili de sacrificiu. Puțini mai recunosc faptul că pădurile au fost și rămân pentru acest popor român, ,cămară de bunuri, adăpost și tranșeu”. Este de datoria școlii să reamintească asemenea adevăruri, să le cultive în rândul studenților săi, imprimându-le astfel o conștiință forestieră, precum și certitudinea că produsul final al muncii câtorva generații dintre ei, referindu-ne întotdeauna la durata unui ciclu de producție, rămâne peren în folosul națiunii. Aspectele unor atitudini sau politici conjuncturale, ca și tentativele de a considera pădurea capital electoral se dovedesc dezastruoase pentru viitorul silviculturii.

Este normal, așadar, ca atitudinea noastră în direcția formării specialiștilor silvici pentru silvicultura secolului XXI să se caracterizeze prin clarviziune în definirea planurilor de învățământ, fixarea disciplinelor de studiu, modernizarea stagiilor de practică didactică și, nu în ultimul rând, a cifrelor de școlarizare.

Acreditând larg ideea că pădurile României, neasemuite întru frumusețe și valoare eco-productivă, constituie un patrimoniu de interes național, nu o putem dezlipi, în procesul de învățământ, de adevărul că perenitatea pădurii este indisolubil legată de perenitatea națiunii române. Este vorba de înțelesul corect al noțiunilor, de semnificația durabilă ce o capătă știința silvică și nevoia, da, nevoia de a demonstra existența noastră europeană cu mult înainte de sosirea și permanentizarea în occident a unor popoare migratoare.

Neîndoielnic, generoasa emblemă a acestui simpozion, „Pădurile secolului XXI în România”, oferă câmp liber multor extrapolări, ceea ce ne poate înaripa pe mulţi. În sfera formării de specialiști ne menținem, însă, în cadrul pragmatic al realităţilor prezente și viitoare, fiindu-ne îngăduit să visăm cu ochii deschiși la dimensiunea de mâine a fondului nostru forestier, la o structură administrativă mai puțin expusă experimentelor și neinițiaţilor, la durabilitatea simțământului civic și a conștiinței forestiere la români.

Pe aceste coordonate, nu omitem capacitatea de absorbție a specialiștilor silvici de către unitătile de profil, la nivelul contingentelor dimensionate după criterii mai mult sau mai puțin subiective în condițiile actuale de înţelegere și interese.

Cele înfăţişate exprimă o schemă cu totul neîncăpătoare de principii și considerente ce punctează o vedere proprie a ceea ce trebuie să fie, în afara clasificărilor din cataloage sau a judecăţilor din consilii de orice fel, profilul profesional al inginerului silvic - astăzi, mâine și întotdeauna. Viața ne va ajuta ca de fiecare dată să ne modelăm acțiunile, dorim însă să ne regăsim în toate împrejurările într-o ținută sobră, responsabilă pentru viitorul silviculturii din țara noastră, context în care tinerii ce aspiră la această profesiune să dobândească, încă din perioada de formare în facultate, certitudinea că vor sluji prin pădure o instituție perenă, situată cu demnitate între breslele prestigioase ce conferă României conturul mult dorit de stat prosper cu oameni harnici și cinstiţi.

Stăruim în materializarea acestor gânduri, conștienți că învățământul silvic superior are menire de a pregăti oameni capabili a înfăptui programe concrete de evaluare, pe trepte sociale noi, a rolului și funcțiilor pădurii în secolul ce vine.

Vă mulțumesc pentru atenție!

17 martie 1992

Prof.dr.ing. Ioan Milescu

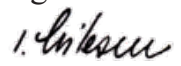




\section{Ioan Milescu [1928 - 2018] - note biografice}

Silvicultor român născut la 13 august 1928 în comuna Hulubeşti, judeţul Dâmboviţa.

A absolvit liceul „Aurel Vlaicu” din Bucureşti (1948) şi Institutul de Silvicultură din Câmpulung Moldovenesc (1952). În noiembrie 1957 susţine, la Academia Tehnică Silvică din Sankt Petersburg, teza de doctorat cu tema „Organizarea amenajistică a pădurilor din judeţul Suceava în legătură cu valorificarea lor industrială”.

Şi-a desfăşurat activitatea în învăţământul superior silvic, în cercetarea ştiinţifică şi producţia silvică fiind, pe rând: preparator şi asistent (1951-1953), şef de ocol la O.S. Vidra, judeţul Vrancea (19541956), şef de laborator şi şef de secţie la Institutul de Cercetări şi Proiectări Silvice (1957-1961), director în Ministerul Economiei Forestiere (1961-1963), şef de secţie de specialitate în cadrul Secretariatului General al Consiliului de Miniştri (19641972), director al Institutului de Cercetări şi Amenajări Silvice (1973-1976), inspector general - şef de compartiment tehnic în Ministerul Silviculturii (1977-1990), profesor (1990-2018) şi decan (1990-2002) al Facultăţii de Silvicultură la Universitatea „Ştefan cel Mare" din Suceava.

Activităţile desfăşurate nu l-au îndepărtat sub nici o formă de munca ştiinţifică în domeniul forestier fiind în permanenţă angajat prin acţiuni şi iniţiative în organizarea şi realizarea nemijlocită a programelor de studii, de cercetare şi valorificare a dimensiunii resurselor forestiere naţionale şi europene, în evidenţierea caracteristicilor şi valorii economice, a indicatorilor de sinteză a funcţiilor pădurii, în fundamentarea sistemului românesc de gospodărire eficientă şi durabilă a pădurilor.

Personalitate marcantă a silviculturii româneşti şi recunoscut pentru activitatea de co78 laborare cu specialişti de profil din Europa, S.U.A. şi Canada, a publicat 185 lucrări şi articole în reviste de specialitate din ţară şi din străinătate, având, de asemenea, numeroase alte contribuţii sub formă de conferinţe şi referate ştiinţifice la diferite manifestări, recenzii şi cronici.

Între lucrările elaborate şi publicate, 45 sunt cărţi, monografii şi sinteze în domeniu, dintre care 6 cursuri universitare ca unic autor, 13 monografii şi lucrări de sinteză ca autor principal şi 26 lucrări cu referire la silvicultura naţională, realizate ca singur autor sau în colaborare, multe dintre acestea prezentate la manifestări internaţionale de prestigiu, precum Congresele forestiere mondiale de la Seattle (S.U.A.), Madrid (Spania), Buenos Aires (Argentina), Djakarta (Indonezia), Ciudat de Mexico (Mexic) sau Congresele Uniunii Internaţionale a Institutelor de Cercetări Forestiere de la Gainesville (S.U.A.), München (Germania), Tampere (Finlanda).

$\mathrm{Ca}$ o recunoaştere a acestor realizări, a fost ales membru corespondent (1969) şi apoi membru titular (1991) al Academiei de Ştiinţe Agricole şi Silvice "Gheorghe Ionescu-Şişeşti", iar în 1972 i s-a acordat premiul Academiei Române pentru lucrarea monografică ,Fagul”.

Contribuţiile sale sunt apreciate pozitiv în rândul silvicultorilor români şi europeni, menţinându-şi, prin consistenţa şi veridicitatea rezultatelor obţinute, deplina actualitate, în ciuda modificărilor sau reconsiderărilor impuse în timp de schimbarea regimului social.

Ca făuritor de şcoală silvică de nivel universitar în Bucovina, zona cea mai împădurită a ţării şi cu tradiţie în prelucrarea lemnului, profesorul Ioan Milescu rămâne în memoria colegilor şi discipolilor săi din Universitatea "Ştefan cel Mare" din Suceava ca un reprezentant de prestigiu, fiind considerat unanim ca un slujitor echilibrat şi cu spirit vizionar în slujba pădurii româneşti. 